\title{
Customer Relationship Management on Googol Soft Technologies
}

\author{
G.Madan, R. Ramamoorthy, Vimala.D
}

\begin{abstract}
The best organization challenge in the new thousand years of progression and globalization for a business is to serve and keep up incredible relationship with the master - the customer. In the past producers thought little of their customers, because around then the customers were not mentioning nor had elective wellspring of supply or suppliers. Nevertheless, today there is an extraordinary change. The changing business condition is depicted by money related movement, growing competition, high buyer choice, mentioning customer, more complement on quality and estimation of acquirement, etc.
\end{abstract}

All of these movements have made the present producer move from regular displaying to current advancing. Present day promoting calls for more than structure up a thing, esteeming it, propelling it and making it accessible to target customer. It solicitations building trust, a coupling force and worth included relationship with the customers. The path toward structure up a supportive and agreeable association between the buyer and shipper is considered customer relationship the officials in a matter of seconds called CRM. The likelihood of CRM is to know the individual customer actually, with the objective that the association has a changed thing arranged for him even before he demands it.

Keywords : sociology, generalizabiliyt discernments

\section{INTRODUCTION}

By and large markets for the normal and standard healing plants have expanded premium. The Indian beautifiers industry acknowledge an essential occupation in ayurvedic and home created improving experts area since India is normally solid in this field. The world home created market yields 51210 crores pay. In this present China's offer is 18,000 crore, yet India's offer is just 280 crore. To improve Indiaes share in the general market, nature of social security things ought to be tapped and broadened. The first being the improvement for the excitement for Indian financially able things and the second being the all-encompassing getting power of the normal Indian. For example, home created improving authorities from India have an unprecedented excitement for the abroad market and different medicinal

Revised Manuscript Received on July 22, 2019.

G.Madan, A,Department of MBA, Bharath institute of Higher Education \& Research,Tamilnadu,India, EmailMadang@ gmail.com

Mr. R. Ramamoorthy Assistant Professor,Department of MBA, Bharath institute of Higher Education \& Research,Tamilnadu,India, Email: ramamoorthy0071@gmail.com

Vimala.D, Assistant Professor,Department of CSE, Bharath institute of Higher Education \& Research,Tamilnadu,India, Email vimalamuthu3@gmail.com things that are made in India today are given to comprehensive providers of checked wonderfulness care things like The Body Shop for instance. New feelings that have been disclosed by a development of improving pros business highlight evaluation India uncover that different International affiliations are legitimately redistributing beauty care products to India and that the matter of therapeutic things India is making at a regular pace of for all intents and purposes $20 \%$ yearly. [1],[3],[5]

\section{RESEARCH STUDY}

Descriptive type of research has been adopted for this research and description of a phenomenon or characteristics associated with the population are also dealt with.

Zone studies are interdisciplinary fields of research and grant relating to specific geological, national/government, or social districts. The term exists essentially as a general depiction for what may be, in the act of grant, numerous heterogeneous fields of research, including both the sociologies and the humanities. Run of the mill territory studies projects include history, political theory, humanism, social investigations, dialects, geology, writing, and related controls.

The study is conducted in marketing department of Googol soft Technologies in Chennai. Googol soft Technologies has customers from all over the India. [2 ],[ 4],[6]

\section{DATA ANALYSIS AND INTERPRETATIONS}

Table 1: Showing the association of customers with Googolsoft Technologies International

\begin{tabular}{|l|l|l|l|l|}
\hline & & Frequency & Percent & Valid Percent \\
\hline \multirow{4}{*}{ Valid } & <1 year & 18 & 18 & 18 \\
\cline { 2 - 5 } & $1-2$ years & 28 & 28 & 28 \\
\cline { 2 - 5 } & 2-3years & 36 & 36 & 36 \\
\cline { 2 - 5 } & >3years & 18 & 18 & 18 \\
\cline { 2 - 5 } & Total & 100 & 100.0 & 100.0 \\
\hline
\end{tabular}


FIG 1:\%Customers across years

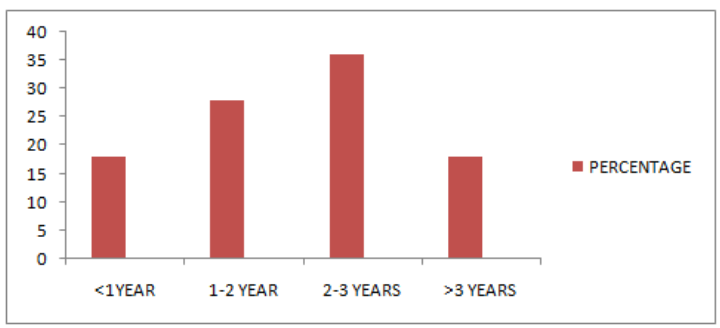

\section{Inference:}

The above chart shows that $36 \%$ of customers are availing services from Googolsoft Technologies for more than 2 years to less than 3 years, $28 \%$ are availing services for more than 1-2 years, [26],[28],[30]18\% are availing services from less than 1 year and $2 \%$ are availing services from more than 3 years. Hence, the service lag has been there that has to be improved with customers of Googolsoft Technologies. [8],[ 10] ,[12]

\section{RESULTS}

$>$ It was found that majority of GOOGOLSOFT's customers are availing services from the company from 2 to 3 years. [25],[27],[29]

$43 \%$ of customers availed Web Development Services from GOOGOLSOFT TECHNOLOGIES and only $8.3 \%$ have approached for Placement and Executive search.

$>$ Out of 60 customers $65 \%$ of the customers had shifted to GOOGOLSOFT TECHNOLOGIES from other companies. Out of that $69 \%$ of customers availed the same services from Photon InfoTech and Kumaran Systems and other customers equally availed from other local companies. [20],[22], [24]

$>48.7 \%$ of the customers availed Placement and Executive search, $30.8 \%$ have availed software services, and $20.5 \%$ Business Consulting and none of the customers have availed Placement and Executive search from other companies.

$>$ In case of personnel, customized solutions and communication other companies were found to be outstanding than GOOGOLSOFT. [13], [15] ,[ 17]

$>$ Majority of the customers considered promptness, personnel, communication, price, post service delivery as most important attributes in the level of service.

$>$ Communication, customized solutions and personnel are the areas where GOOGOLSOFT TECHNOLOGIES is operating below average. [19],[21],[23]

$>$ Only $13.3 \%$ of customers had encountered problems while availing services and the problem has been immediately resolved for $62.5 \%$ of customers and for the rest it was still unresolved.

Majority of $66.7 \%$ suggested changes to GOOGOLSOFT TECHNOLOGIES regarding communication and the rest suggested change regarding bill submission. It was found that GOOGOLSOFT TECHNOLOGIES had partially changed according to customer needs. [31],[33]
$>66.7 \%$ of customers rated the overall services of GOOGOLSOFT TECHNOLOGIES as good and only $25 \%$ rated as fair.

\section{CONCLUSIONS}

$>$ The response levels of Googolsoft Technologies customers were good and the problems were rectified with least MTBF support system.

$>$ The overall services provided by Googolsoft Technologies were good.

$>$ The customers' expectations are yet to be met by Googolsoft Technologies to provide customized products. This can be achieved only through effective R\&D Plant.

\section{REFERENCES}

1) BharthVajan R., Ramachandran S.,Psychographic dimensions of training,2016,International Journal of Pharmacy and Technology,V-8,I-4,P-23727-23729

2) Balakrishnan P., Bharthvajan R.,A study on human resource planning in hospitals in Chennai City,2014,International Journal of Applied Engineering Research,V-9,I-22,P-7503-7507

3) Priyadarsini P., Bharthvajan R.,Role of emotional intelligence training programme in reducing the stress of the nurses,2014,International Journal of Applied Engineering Research,V-9,I-22,P-7411-7421

4) Kerinab Beenu G., Bharthvajan R.,Empirical analysis on the cosmetic buying behavior of young women in South India,2014,International Journal of Applied Engineering Research,V-9,I-22,P-7361-7366

5) Balakrishnan P., Bharthvajan R.,Whistling in the wind,2014,International Journal of Applied Engineering Research,V-9,I-22,P-7586-7593

6) Krishnan B., Peter M.,Health hazards of Indian Bpo employee-an alarming issue,2014,International Journal of Applied Engineering Research,V-9,I-22,P-7336-7341

7) Kerinab Beenu G.H., Peter M.,Role of insurance in economic development,2014,International Journal of Applied Engineering Research,V-9,I-22,P-7532-7539

8) Balakrishnan P., Peter M., Priyadarsini P.,Efficiency of safety measures for wellbeing of employees in manufacturing industry,2014,International Journal of Applied Engineering Research,V-9,I-22,P-7376-7382

9) Anbarasi M., Praveen Kumar S.,Online sales promotions of herbal products and its effectiveness towards tanisha.com,2019, Indian Journal of Public Health Research and Development,V-10,I-1,P-195-200

10) Anbarasi M., Praveen Kumar S.,Various online marketing and promotions strategies to improve the validation towards the organic products in the pharmaceutical sectors,2019,Indian Journal of Public Health Research and Development,V-10,I-1,P-263-269

11) Loganathan R., Praveen Kumar S.,Grievance handling a key factor for solving issues of employees in an organization,2014,International Journal of Applied Engineering Research,V-9,I-22,P-7483-7491

12) Loganathan R., Praveen Kumar S.,Study on preference of private label brands in super and Hypermarkets,2014,International Journal of Applied Engineering Research,V-9,I-22,P-7327-7335

13) Smitha M., Praveen Kumar S.,Understanding stress and its managementamong the nurses in Chennai city,2014,International Journal of Applied Engineering Research,V-9,I-22,P-7560-7565

14) Kerinab Beenu G.H., Praveen Kumar S.,A study on the investment behavior of Chennai investors in mutual fund schemes,2014,International Journal of Applied Engineering Research,V-9,I-22,P-7520-7525

15) Loganathan R., Praveen Kumar S.,Retention strategies key for organizational productivity,2014,International Journal of Applied Engineering Research,V-9,I-22,P-7443-7447

16) Pavithra J., Ganesan M., Brindha G.,State wise analysis of microfinance sector in India,2016,International Journal of Pharmacy and Technology,V-8,I-4,P-23417-23432

17) Pavithra J., Ganesan M.,A comparative study on microfinance in India and abroad,2016,International Journal of Applied Business and Economic Research,V-14,I-8,P-5471-5476 
18) Pavithra J., Ganesan M.,A study on awareness and impact of micro-financial schemes,2016,International Journal of Applied Business and Economic Research,V-14,I-8,P-5449-5460

19) Senthilmurugan P., Pavithra J.,Consumer preference towards organised retailing with reference to Big Bazaar,2014,International Journal of Applied Engineering Research,V-9,I-22,P-7469-7475

20) Senthilmurugan P., Pavithra J.,Implication of social media marketing in growing healthcare industry,2014,International Journal of Applied Engineering Research,V-9,I-22,P-7448-7456

21) Loganathan R., Pavithra J.,Consumer perception towards private label brand over other brands in super markets and hypermarkets,2014,International Journal of Applied Engineering Research,V-9,I-22,P-7355-7360

22) Kerinab Beenu G., Pavithra J.,Tradeâ€"off between liquidity and profitability in logistics industry,2014,International Journal of Applied Engineering Research,V-9,I-22,P-7398-7401

23) Kerinab Beenu G., Pavithra J.,A study on the prospective consumerâ€ $€^{\mathbf{T M}_{S}}$ perception towards utility cars in Chennai city,2014,International Journal of Applied Engineering Research,V-9,I-22,P-7526-7531

24) Pavithra J., Dilli Babu P., Ambuli T.V.,A study on budgetary control at Maruti Service Masters, Chennai,2014,International Journal of Applied Business and Economic Research,V-12,I-2,P-151-161

25) Pavithra J., Dilli Babu P., Ambuli T.V.,A study on customer satisfaction of retro Garments Pvt Ltd, Chennai,2014,International Journal of Applied Business and Economic Research,V-12,I-2,P-381-391

26) Kerinab Beenu G.H., Pavithra J., Senthilmurugan P.,A study on the influence of promotional activities for TATA ARIA among consumers in Chennai,2014,International Journal of Applied Engineering Research,V-9,I-22,P-7572-7578

27) Vijayaragavan S.P.,An investigative expert that's general FBG sensors,International Journal of Mechanical Engineering and Technology,V-8,I-8,PP-1500-1505,Y-2017

28) Vijayaragavan S.P.,Equalization routing protocol for Wi-Fi sensor strategy,International Journal of Mechanical Engineering and Technology,V-8,I-8,PP-1662-1666,Y-2017

29) Karthik B., Kiran Kumar T.V.U., Vijayaragavan P., Bharath Kumaran E.,Design of a digital PLL using 0.35 $\hat{\mathrm{I}}^{1 / 4 \mathrm{~m}}$ CMOS technology,Middle East Journal of Scientific Research,V-18,I-12,PP-1803-1806,Y-2013

30) Kanniga E., Selvaramarathnam K., Sundararajan M.,Kandigital bike operating system,Middle - East Journal of Scientific Research,V

31) Jasmin M., Vigneshwaran T., Beulah Hemalatha S.,Design of power aware on chip embedded memory based FSM encoding in FPGA,International Journal of Applied Engineering Research,V-10,I-2,PP-4487-4496,Y-2015

32) Jasmin M.,Optimization techniques for low power VLSI circuits,Middle East Journal of Scientific Research,V-20,I-9,PP-1082-1087,Y-2014

33) Jasmin M., Vigneswaran T.,Fuzzy controller for error control of on - Chip communication,2017 International Conference on Algorithms, Methodology, Models and Applications in Emerging Technologies, ICAMMAET 2017,V-2017-January,I-,PP-1-5,Y-2017

\section{AUTHORS PROFILE}

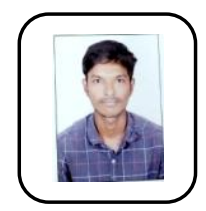

G.Madan Student Department of MBA, Bharath institute of Higher Education \& Research, Tamilnadu, India.Email:kevininfant@gmail.com

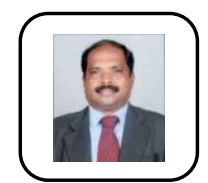

Mr. R. Ramamoorthy Assistant Professor,Department of MBA, Bharath institute of Higher Education \& Research,Tamilnadu,India, Email

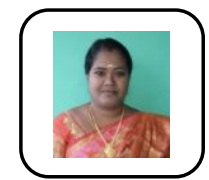

Vimala.D, Assistant Professor,Department of CSE, Bharath institute of Higher Education \& Research,Tamilnadu,India, 